\title{
MACEDONIAN SECURITY CROSSROAD IN 21 CENTURY, CONTEMPORARY SECURITY CHALLENGES
}

\author{
Mladen Trajkov, MA \\ E-mail: mladen.trajkov@gmail.com \\ Aleksandar Nacevski, MA \\ E-mail: aleksandarnacevski@hotmail.com \\ Valentiva Vchkova, MA \\ E-mail: valentina_vckova@yahoo.com
}

\begin{abstract}
The article aims at an analysis of the security challenges that the Republic of Macedonia has been facing at the end of the $20^{\text {th }}$ and the beginning of the 21 century. The basic premise is that these contemporary challenges are a product of the geopolitical position of the Balkans as a crossroad between East and West and the mutual impact of the clashing interests of East and West. Starting with the analysis of the geopolitical challenges in the Balkans and Macedonia, we move towards presentation of the contemporary security challenges, such as terrorism, cyber terrorism, drugs and weapons trafficking, recruitment in foreign armies and the refugee crisis. The internal security challenges are presented in the third part of the article in more depth. Finally we present ways and possibilities for prevention and/or dealing with these contemporary challenges.
\end{abstract}

Keywords: security challenges, geopolitical crossroad, Macedonia

\section{Introduction}

In the XXI century global security trends are burdened with many security challenges among which the most remarkable ones presenting the biggest problem are: terrorism, cyber-attacks, drug trafficking, arms trade and the refugee crisis. Because the geopolitical position of the Republic of Macedonia is in the Balkan crossroads, it is expected that all of this, or at least most of these security challenges have direct impact on 
the security of the state. Even greater dangers for the Balkans are the unfinished process of formation of national states, their recognition and, of course, ideas and fantasies about forming large mononational countries. In that context, the closer and wider environment, the process of development of the Republic of Macedonia is on the road to European Union (EU) and NATO while solving huge neighborhood and other obstacles.

\section{Geopolitical Challenges in the Balkans and Macedonia}

There has been a lot of turbulence and a tumultuous historical framework on the Balkan peninsula in the past 25-30 years, in which very unexpected and unwanted processes occurred for all open-minded citizens: the decay of Yugoslavia, flourish of nationalism, formation of small and weak nation states, wars, refugee crises, collapse and re-establishment of security systems, human suffering, destruction, economic crisis, etc. In such a small space as the Balkan Peninsula is, all these security challenges enabled fast and smooth installation of organized crime. Above all, for providing necessary weapons to conduct wars, the required drugs, the required professional fighters (Dogs of War) from around the world, especially from the Muslim world with a large penetration of religious fanatics (jihadists) which enable penetration and installing of terrorism in a front door at the gates of Europe and of course, human trafficking that is gaining momentum. Balkans was and remain a powder keg of Europe and the world, because here were the largest fights in I and II World War. Here the interests and cultures of East and West overlap, meet, clash and the Balkan region is in constant controllable or sometimes uncontrollable instability. In that kind of constellation of security challenges, field of neighborly denial, poor security cooperation, bilateral and regional, turbulent beginning of XXI century happen in the Balkans.

\section{Contemporary Secuirty Challenges in the $21^{\text {st }}$ Century}

The general impression of the Balkans is that it was not ready to welcome the tumultuous early XXI century, in which all modern security challenges become too large, intractable problem for independent action of security structures. That security conditions, against their will forced security services to have to cooperate at the bilateral, regional and international level. Cooperation primarily refers to the exchange of security information on people and events that are a common problem of the wider community and address the challenges that will process a little wider: 
- Terrorism

- Cyber attacks

- Illegal trafficking in drugs

- Illegal arms trade

- Serving in a foreign army

- Refugee Crisis

\section{Terrorism}

Terrorism, as never before, in the second half of XX and early XXI century is a world number one problem that everyday extends its tentacles and threats everywhere, like some octopus with 1000 feet and hands. Phenomenon of terrorism has changed in terms of the objective: in the beginning the intention was to show that there is an organization but today the intention is to show its power, murderous, ruthlessness and more. Initially, the target were the state security organs and their officials, some politicians and innocent citizens, but today they want to cause more casualties, material and immaterial damages which acquires and changes public opinion about an organization, condition, attract new members, financiers, blackmail governments, powerful corporations and others.

\section{Cyberattacks}

The development of new technologies and expansion and industrialization in the world, enabled rapid development in electronics, telecommunications, communication facilities, utilities. The banking sector will have to financially secure all of these technological challenges. These extra fast development processes are very positive, but on the other hand they are extremely negative because they faced with unwilling cumbersome security systems which should cope with the new modern technological challenges. Skilled users of new technologies, are striving daily to harm the national and international organizations and thereby jeopardize world safety. The most dangerous are the cyber attacks that aim breaking down the security system of the countries, financial institutions, etc., where is impossible to calculate damages. Examples of this groups are "Anonymous"19, "Wikileaks" and other marked and named and unnamed groups and structures. The biggest cyber attacks in history are: "Titan Rain", "Moonlight Maze", "Presidential Espionage", "750.000 american zombies", "Worldwide Web Slowdown"20. Examples for this kind of actions can

$\underline{19}$ http://mkd-news.com/vojnata-na-idninata-veke-pochna, како и http://vistinomer.mk/neispolneto-ne-e-vospostaven-tsert-tim-za-upravuvane-so-sajber-napadi/

${ }^{20}$ http://www.fakulteti.mk/news/13-07-14/najgolemite_sajber_napadi_vo_istorijata.aspx 
be found in the last presidential campaign in the United States and the election of Donald Trump for president ${ }^{21}$. Cyber attacks against "Yahoo" affected more than 1 billion users ${ }^{22}$. After all, Europol and other security organizations worldwide fight against this evil and they managed to crack the largest cyber network Avalanche (Avalanche) ${ }^{23}$. These are new and modern challenges and the main threats to information security today, writes Bakreski, and he presented the following types of threats:

1. Cyber - terrorism;

2. Cyber - organized crime;

3. Information sabotage (the external and internal structures);

4. Cyber - Crime (external and internal structures);

5. Cyber - hooliganism (external and internal structures)24.

About new and contemporary threats to Macedonia writes Mircheska, where she is presenting definitions of cyber terrorism, cyber crime, and the legal framework for the fight against this kind of threat in the Republic of Macedonia and provides an example of cyber attack called "Estonian case"25.

\section{Illicit trafficking in drugs}

Contemporary challenge of the second half of XX and early XXI century presents the growing production, trade and use of drugs and precursors. Even more tragic is that users begin at younger age, even as pupils in primary and secondary school. The relevance of this contemporary challenge is even greater knowing that as an individual element of organized crime it operates autonomously and independently but is closely linked to other elements of organized crime, primarily because of the huge financial effects that can be achieved with it. This paper will only present effects in the fight against this modern evil in the country, which are not large, because it is assumed that the real figures are about ten or more times higher.

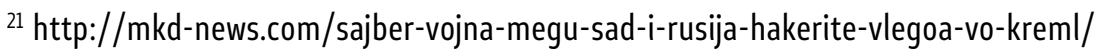
22 http://standard.mk/sajber-napadite-protiv-yahoo-zasegnale-nad-1-milijarda-korisnici/ ${ }^{23}$ http://radio105bombarder.com/svet/razbiena-najgolemata-svetska-sajber-mrezha/ ${ }^{24}$ Bakreski Oliver, "New Security Challenges", Police Academy Annual , 2007, p.13 ${ }^{25}$ Mircheska Nadica, "Cyber terrorism - a modern form of terrorism as Republic Macedonia is vulnerable to cyber terrorism", Almanac of the Faculty of Security, 2010, p.122.
} 


\section{Security}

Table. 1 Statistical data on criminal offenses against human health related to the unauthorized manufacture and sale of narcotic drugs, psychotropic substances, precursors and providing of their use $\mathrm{e}^{26}$.

\begin{tabular}{|l|l|l|l|l|l|l|l|l|l|}
\hline \multicolumn{1}{|c|}{ year } & 2007 & 2008 & 2009 & 2010 & 2011 & 2012 & 2013 & 2014 & 2015 \\
\hline Crimes against public health & & & & & & & & & \\
\hline $\begin{array}{l}\text { Unauthorized manufacture } \\
\text { and sale of narcotic drugs, } \\
\text { psychotropic substances, } \\
\text { precursors }\end{array}$ & 354 & 317 & 378 & 522 & 484 & 437 & 465 & 443 & 436 \\
\hline $\begin{array}{l}\text { Enable usage of narcotic } \\
\text { drugs, psychotropic sub- } \\
\text { stances and precursors }\end{array}$ & 46 & 50 & 57 & 78 & 65 & 74 & 97 & 87 & 60 \\
\hline Total & 400 & 367 & 435 & 600 & 551 & 511 & 562 & 530 & 496 \\
\hline
\end{tabular}

\section{Illicit arms trade}

Besides the approved and legally regulated arms trade, the danger in the modern world and in the Republic of Macedonia is illicit arms trafficking. Restless Balkans, which until about 15-20 years ago was a ground for wars, the loss of lives, property and destruction, nowadays still is a market where you can buy and sell weapons. In Albania, in 1997 there was a collapse of the state and the population stole from military warehouses large amount of any type of weapon. According to Salim Kjerimi "in Albania, aggressive masses stole from the open depots of the Armed Forces of Albania 2 million assault rifles like "AK-47" and "AK-74", including tanks, armored vehicles, cannons and other hard antiaircraft and antipersonnel weapons, 1.5 billion bullets and other munitions, 3.5 million offensive and defensive hand grenades, 1 million anti-personnel mines, 840,000 cannon ammunition of various calibres, as well as 350,000 tons of dynamite and Tritol."27 In this context we can use Babanovski's book, "ONA, Terrorist paramilitary in Macedonia", which has published many details of Albanian weapons warehouses and other activities on the topic of illicit arms trafficking..$^{28}$ After sedation and normalization of the situation in the Balkans, this weapon finds its way to the new crisis and war regions bringing enormous profit for traders. That the situation with the illicit arms trade flourishes show us the last

${ }^{26}$ The table is prepared according statistic data released by the State Statistical Office of the Republic of Macedonia in its Statistical reviews (Perpetrators of crimes for the years 2007-2015). ${ }^{27}$ The text is taken from an interview with historian and career diplomat Salim Kerim: "20 godini podocna: što se sluči vo Albanija vo 1997 godina?", Utrinski vesnik, accessed http://utrinski.mk/ ?ItemID=2D97BDD3C74615449EB32BF54E91C40B

${ }^{28}$ Ivan Babanovski, NLA Terrorist militias in Macedonia, Veda - Skopje, 2002, p.60. 
coordinated police action led by Europol and conducted in 11 countries: Spain, Belgium, Britain, Bulgaria, Cyprus, Finland, Greece, Netherlands, Poland, Romania and Sweden, where 664 weapons and 34,000 pieces of ammunition, bombs and silencers were seized. ${ }^{29}$ According to presented material, we can expect a large quantities of illegal weapons to exist in the Republic of Macedonia, presented by official statistics from the National Institute of Statistics.

Table. 2 Statistics for criminal offenses against public order, unauthorized manufacture, possession, mediation, trade with weapons or explosives ${ }^{30}$

\begin{tabular}{|l|l|l|l|l|l|l|l|l|l|}
\hline year & 2007 & 2008 & 2009 & 2010 & 2011 & 2012 & 2013 & 2014 & 2015 \\
\hline $\begin{array}{l}\text { Crime against public order } \\
\text { and peace }\end{array}$ & & & & & & & & & \\
\hline $\begin{array}{l}\text { Unauthorized manufacture, } \\
\text { possession, mediation, trade } \\
\text { with weapons or explosives }\end{array}$ & 203 & 220 & 199 & 192 & 180 & 168 & 165 & 141 & 127 \\
\hline
\end{tabular}

According to the chart review you can clearly see the downward trend of the criminal charges for trafficking in Macedonia, which could be the result of reduced police efficiency, or reduced demand and supply of weapons, or perhaps something else.

\section{Serving in a foreign army}

Open military hot spots of the Middle East in Afghanistan, Iraq, Syria and their closest surroundings and especially the activities of "Al Qaeda" and "Islamic State or ISIL or ISIS," especially on the popularization of their activities through the Internet and other mass media contributed to gaining adherents and followers around the world. This contributed to the popularization of the involvement of a growing number of foreign fighters in the lines of these terrorist organizations.

This is about a two-way process and source of radical primarily Muslim ideas from this part of the world all over the world and the second process is to find followers around the world and involvement in the activities of these terrorist organizations, whether on the battlefield, either in the process of spread of ideas or in the process of recruiting new fighters and financing activities.

${ }^{29}$ The article is entitled: 245 people across Europe arrested for trafficking in weapons, 24/01/2017, http://daily.mk/svet/uapseni-245-lica-shirum-evropa-trgovija-oruzhje

${ }^{30}$ The table is prepared according statistic data released by the State Statistical Office of the Republic of Macedonia in its Statistical reviews Perpetrators of crimes for the years 2007-2015 
Until recently the Balkans was a military hot spot but today Balkans becomes a major exporter of fighters from the Balkan countries that are joining the ranks of "Al Qaeda" and "Islamic state." Because the problem with this activity began to concern not only the crisis region of the Middle East, but also the other parts of the world, states have attempted to address this problem by adopting appropriate legislation.

Republic of Macedonia, following the recommendations of international security organizations and their needs for changes in their own criminal legislation, made changes to the Criminal Code, where was added a new Article 322-A, entitled "Participation in a foreign army, police paramilitary or paramilition formations". ${ }^{31}$ These legislative changes governing participation in a foreign army or police, through a basic paragraph and nine qualifier forms and in terms of penalty policy for the basic paragraph the punishment is at least 5 years in prison and for the qualifier types it changes and can be at least 4 years p. 4,1 to 5 years in prison for $p$. 6, or the offender may be released provided legal solution. Legal solution which occurs as a reflection of the increased volume of outgoing Macedonian citizens to foreign battlefields was confirmed by President Gjorge Ivanov who said: "Macedonia currently has 110 fighters in Syria, 25 dead and 69 are returned to the country. ${ }^{132}$ Precisely to prevent these persons returnees from war regions participated and returned to Republic of Macedonia, security services undertook a number of activities and brought two operating actions: Cell 33 and Cell $2^{34}$, to find, capture and bring to court the persons who participated in various ways in foreign armies. It is expected that bringing in front the judicial bodies of the participants in such activities, can have preventive significance than people thought to go and participate in foreign battlefields, but it doesn 't solve the problem with these fighters. Another reason is the motive that forced these people to leave on foreign battlefields: ideology, money, desire to kill or something else. That elimination of these causes may contribute to a reduction in support for this kind of radicalism in the world and certainly in our country.

\footnotetext{
31 The changes were made in: Law on amendments to Criminal Code, Official Gazette No.132 of 05.09.2014

32 Available at: http://www.dw.com/mk/\%D0\%BC\%D0\%B0\%D0\%BA\%D0\%B5\%D0\%B4\%D0\%BE \%D0\%BD\%D0\%B8\%D1\%98\%D0\%B0-\%D0\%BD\%D0\%B5 \%D1\%81\%D1\%82\%D1\%80\%D0\%B0\%D0\%B2\%D1\%83\%D0\%B2\%D0\%B0-\%D0\%BE\%D0\%B4-\%D0\%B1\%D0\%B0\%D0\%BB \%D0\%BA\%D0\%B0\%D0\%BD\%D1\%81\%D0\%BA\%D0\%B8-\%D1\%84\%D1\%80\%D0\%BE\%D0\%BD\%D1\%82-\%D0\%BD\%D0\%B0-\%D0\%B8\%D1\%81\%D0\%BB\%D0\%B0\%D0\%BC\%D1\%81\%D0\%BA\% D0\%B0\%D1\%82\%D0\%B0-\%D0\%B4\%D1\%80\%D0\%B6\%D0\%B0\%D0\%B2\%D0\%B0/a-18887153, (accessed on 20.01.2017)

33 http://www.akademik.mk/sluchaj-kjelija-obvinetite-za-uchestvo-vo-stranska-vojska-ja-priznaa-vinata/, and http://revolucionermk.com/presudi-za-obvinetite-vo-sluchajot-kelija/ 34 http://kurir.mk/makedonija/vesti/uapsenite-vo-kelija-2-so-golemo-teroristichko-iskustvo/
} 


\section{Refugee crisis}

Processes refugee crisis began with the "Arab Spring" and intensified with the appearance and activities of the terrorist organization "Islamic State" in Syria. Balkan processes of the refugee crisis enabled certain criminal structures, alter or supplement their daily activity, with, at times very useful and financially rewarding activity, human trafficking and migrant smuggling.

At the same time, this process is used by radical terrorist structures to shift their radical fighters around the world as refugees, whereas later they are able to use them for their own goals and ideas. For the presentation of the situation in this criminal activity, statistical indicators that are presented by the National Commission for Combating Human Trafficking and Illegal Migration for a period of six years, from 2010 to 2015 , are used. Statistical indicators are perhaps small because "dark figure" in this activity as well as in other areas of organized crime is high, primarily because of the large amounts of funds in circulation and of course because of corruption and the involvement of representatives of the police and other state structures in these organizations, quote: "During $2014 \mathrm{MOI}$ of RM has conducted 6 investigations involving 8 police officers (of which 1 deputy superintendant of Sol 1 Commander of the police station and other police officers). Criminal charges are filed to the competent public prosecutor against all 8 and 7 of them have been given detention. By the Sector for Internal Control and Professional Standards were initiated procedures for establishing disciplinary responsibility." 35 Because in addition to activities with the refugee crisis appears particularly dangerous trafficking, represented are some statistical indicators for this activity.

${ }^{35}$ National Commission for Combating Trafficking in Human Beings and Illegal Migration, Annual Report 2014, p.23 


\section{Security}

Trafficking $^{36}$

Table. 3 Criminal charges, offenders and victims of trafficking in 2010

\begin{tabular}{|c|c|c|c|}
\hline Criminal charges (CC) & Criminal law of RM & offenders & victims \\
\hline КП со КУ бр.27/10 од 27.04.2010 & $\begin{array}{c}\text { Чл.418-г, par.1,2,3 } \\
\text { and } \\
418 \text {-6, par.1 }\end{array}$ & 7 & 2-minors \\
\hline КП со КУ бр.44/2010 од 11.06.2010 & Art.418 -г & 2 & 2- minors \\
\hline КП со КУ бр.64/2010 од 16.09.2010 & Art.418 -г, par.1,2 & 3 & 1- minor \\
\hline $\begin{array}{c}\text { Potential victims - Macedonian } \\
\text { nationals exploited abroad (deceptive } \\
\text { marriage) }\end{array}$ & & & 5- minors \\
\hline $\begin{array}{l}\text { CC submitted by SIA Stip } \\
\text { (under investigation) }\end{array}$ & Art.188 и Art.192 & & 2- minors \\
\hline TOTAL & 3-КП по 418 - г & 25 & 12 \\
\hline
\end{tabular}

Table. 4 Brought criminal charges, offenders and victims of trafficking in 2011

\begin{tabular}{|c|c|c|c|}
\hline Submitted CC & Criminal law of RM & offenders & migrants \\
\hline 27 & Art. 418-6 & 44 & 95 \\
\hline 2 & Art. 418 - B & 8 & 78 \\
\hline TOTAL 29 & & 52 & 173 \\
\hline
\end{tabular}

Table. 5 Brought criminal charges, offenders and victims of trafficking in 2012

\begin{tabular}{|c|c|c|c|}
\hline Submitted CC & Criminal law of RM & offenders & victims \\
\hline 3 & Art. 418 - a & 6 & 5 \\
\hline 1 & Art. 418 - r & 1 & 3 \\
\hline TOTAL 4 & & 7 & 8 \\
\hline
\end{tabular}

Table. 6 Brought criminal charges, offenders and victims of trafficking in 2013

\begin{tabular}{|c|c|c|c|}
\hline Submitted CC & Criminal law of RM & offenders & victims \\
\hline 1 & Art. 418 - r & 1 & 1 \\
\hline TOTAL & & 1 & 1 \\
\hline
\end{tabular}

${ }^{36}$ Tables have been prepared according to the data presented in the 2010-2015 annual reports of the National Commission for Combating Human Trafficking and Illegal Migration 
Table. 7 Brought criminal charges, offenders and victims of trafficking in 2014

\begin{tabular}{|c|c|c|}
\hline Submitted CC & Criminal law of RM & offenders \\
\hline 2 & Art. 418a & 2 \\
\hline 79 & Art.418 -6 & 122 \\
\hline 4 & Art.418-в & 23 \\
\hline 1 & Art.418 -r & 2 \\
\hline TOTAL 86 & & \\
\hline
\end{tabular}

Table. 8 Brought criminal charges, offenders and victims of trafficking in 2015

\begin{tabular}{|c|c|c|}
\hline Submitted CC & Criminal law of RM & offenders \\
\hline 2 & Art. 418a & 3 \\
\hline 129 & Art.418 -6 & 164 \\
\hline 2 & Art.418-B & 23 \\
\hline 1 & Art.418 -г & 3 \\
\hline 25 & Art.418 - & 39 \\
\hline Total 159 & & 232 \\
\hline
\end{tabular}

\section{Smuggling of migrants ${ }^{37}$}

The second also very profitable activity in the processes of the refugee crisis is smuggling migrants, which are billed for several hundred euros each person. Because of such easy money and poverty, a number of citizens and of course employees of customs, the police, the army, are included in this illegal activity, as direct perpetrators or as "corrupt" accomplices. In the next rows due to spatial features only one tabular statistics on this phenomenon is represented.

${ }^{37}$ The table is prepared according to the data presented in the 2010-2015 annual reports of the National Commission for Combating Human Trafficking and Illegal Migration 
Table. 9 Overview of registered criminal offenses and perpetrators of migrant smuggling in the period 2010-2015.

\begin{tabular}{|c|c|c|}
\hline Year & Criminal offenses & Offenders \\
\hline 2010 & 33 & 55 \\
\hline 2011 & 8 & 19 \\
\hline 2012 & 39 & 70 \\
\hline 2013 & 49 & 97 \\
\hline 2014 & 94 & 166 \\
\hline 2015 & 120 & 212 \\
\hline TOTAL & 343 & 619 \\
\hline
\end{tabular}

\section{Internal Security Challenges}

Since its independence up to date, the Republic of Macedonia has continually been facing minor or major security challenges that directly affect the development and progress of this young and fragile country. Briefly here are represented the key challenges: the looting of weapons from military warehouses in Albania since 1997 as an external factor with internal influence, Kosovo refugee crisis in 1999 when in Macedonia we received 350,000 refugees (Albanians and Roma people), of which good part stayed here and remained in marriage, business interests and many other ways and reasons, the 2001 conflict, with the weapon and ideas from Albania, interests and fighters from Kosovo and beyond, continuing internal political conflicts and requirements - discontent of the Albanian population and top of which political turmoil from 2015 to 2016 with (bombs of Zoran Zaev) and everything else result thereof. Of course, no less significant and ignorable are corruption, partisation, public procurement and profits of tenders, failure of the state system and many other reasons. The problem with longer term obstruction of the parliament by SDSM, "colourful revolution" protests in 2016 and other specified events and activities. A special place in the internal challenges are several external factors: Greece does not recognize the name and directly affect the entry of Macedonia into the European Union and NATO, Bulgaria does not recognize people and language, Serbia does not recognize the church and Albania and Kosovo are initiators and external mentors of the activities of the Albanian population in Macedonia and beyond (common Albanian platform for political parties in Macedonia 2016/2017), which directly interfere in the internal affairs of the country. No less important are the burning of the Macedonian flag in Albania and Kosovo over the years, but as their reflection to Macedonia. 


\section{Ways and possibilities for preventing and dealing with contemporary security challenges}

Capacity-building and overall security system of the country will enable timely and above all preventive measures and actions to prevent or neutralize any terrorist activities in the country. On the other hand the growing trend of the development of telecommunications technology, opens up even greater opportunities for development and activities of organized crime, especially terrorism and certainly well thought-out and coordinated cyber attacks in the world and in the country. Because of such opportunities, there is necessity for rapid formation of an agency that would care for the protection of vital security systems, systems of government and public institutions, the banking sector and of course the citizens of the possible misuse of new technologies, that require many financial expenses, other resources and above all relevant staff.

In the area of human trafficking and illegal migration in the country, the National Commission for Combating Trafficking in Human Beings and Illegal Migration in the Republic of Macedonia, prepared during 2006: Strategy for Combating Trafficking in Human Beings in the Republic of Macedonia, National Action Plan to combat human trafficking and illegal migration in the country, the Action plan to combat child trafficking in the country. For this purpose, harmonized legislation, raised and harmonized international and regional police cooperation and certainly provided concrete steps for training staff to deal with this kind of criminal activity. In the process of education arevincluded: IOM, OSCE and the Ministry of Interior. Regarding the illicit arms trade is necessary to eliminate the reasons that cause this phenomenon and they are "socio-economic factors and political factors design, and certainly geostrategic position that can not be changed. "In terms of organized crime and its influence in the Balkans and Macedonia more can be found in Milosheska's and Kotovcheski's issues. Problems with veterans who served in foreign armies and police forces should primarily be addressed preventively before anyone going to the battleground and if it $s$ not achieved, it is necessary after their return. It is important to eliminate the causes and motives that drive these people to go to the battlefield and then, of course, much easier to overcome this danger. The process with the refugee crisis we, as a small and weak state, can not resolve, but we can make a personal contribution to the allied problem solved together with larger states. In the area of the Republic of Macedonia is ours to provide normal conditions of those refugees who are stuck on our territory and their integration into modern societies in Europe. As to the overall contemporary challenge of the XXI century for Macedonia, it is necessary to strengthen the institutions of the state, their professionalism, cooperation and coordination at all levels; internally, bilateral and multiralateral, local, regional and international levels, especially in the field of security. 


\section{Security}

\section{Conclusion}

At the end, as a conclusion we can emphasize a few points. Necessity of strengthening, development, upgrading, continuous synchronization and cooperation of all security structures with other institutions that have significant meaning and all auxiliary elements of the security services (followed by joint exercises and communication activities). On the other hand, it is continuous technical and technological advancement and personnel that will be incorporated in a system of lifelong training and staff development. The third thing is the good and continuing neighboring, regional and international cooperation of state, institutions and citizens in order to increase security. Fourth, and perhaps most important is internal cohesion for overcoming and easier handling with all issues, especially for contemporary security challenges.

\section{Bibliography \\ Books and articles}

Бабановски И., (2002) ОНА Терористичка паравојска во Македонија, Скопје: Веда. Бакрески 0., (2007), "Нови предизвици за безбедноста", Годишник на Полициската академија, Скопје.

Велани Х. К., и Нухун Џ., (2008), Применета криминалистичка анализа, Скопје: Табернакул.

IOM the UN Migration Agency, Compilation of available data and information, reporting period 1 Dec 2016 - 11 Jan 2017

Канцеларија на Обединетите Нации за дроги и криминал (2010), INODC Трговија со луѓе и криумчарење мигранти, Упатство за меѓународна соработка.

Котовчевски М., (2007), „Организираниот криминал - најсериозна закана за националната безбедност на Република Македонија и за нејзините евроатлански интеграции", во Република Македонија помеѓу самитот во Рига и членството во НАТ0, Скопје, Министерство за одбрана на Република Македонија.

Малиш Саздовска М., (2005), Прирачник за разузнавачки циклус, Скопје: Јофискен.

Мек-кју К., (2009) Проучување податоци и предвидувачка анализа собирање разузнавачки податоци и криминалистичка анализа, Скопје: Табернакул.

Милошевска Т., (2011) „Организираниот криминал како безбедносно-политичка и дестабилизирачки фактор за развој на општествата во транзиција (студија на случај-Република Македонија)", Безбедносни дијалози, 6р.4. 
Министерство за одбрана на Република Македонија, Република Македонија помеѓу самитот во Рига и членството во НАТО, Скопје

Мирческа Н., (2010) „Сајбер тероризам - современ облик на тероризмот колку Република Македонија е ранлива од сајбер тероризмот“, Годишник на Факултетот за безбедност - Скопје.

Митиќ К. и Василевски Г., (2013) „Недозволена трговија со оружје - облик на организиран криминал како дестабилизирачки фактор врз безбедноста на државите во Југоисточна Европа“, Современа македонска одбрана $6 p .25$.

Мојаноски Ц., (2012) Методологија на безбедносните науки -основи- книга прва, Скопје: Факултет за безбедност.

Народен правобранител - Национален превентивен механизам, (2014) Годишен извештај 2014 година - Национален превентивен механизам, Скопје

Народен правобранител на Република Македонија, (2015) Годишен извештај за степенот на обезбедувањето почитување, унапредување и заштита на човековите слободи и права, Скопје

Трост J., (2004) Како се пишува научен труд со примена на акрибија, Скопје: АзБуки.

Херман М., (2009) Моќта на разузнавањето во мир и во војна, Скопје: Академски печат.

Џуклески Г., (2005) Прирачник за соработничка мрежа, Скопје: Јофи-скен. 